\title{
Effects of metalloendoprotease substrates on the human sperm acrosome reaction
}

\author{
P. Thomas and S. Meizel \\ Department of Human Anatomy, School of Medicine, University of California, Davis, CA 95616, \\ USA
}

\begin{abstract}
Summary. The substrates carbobenzyloxyserylleucylamide, carbobenzyloxyglycylleucylamide and carbobenzyloxyglycylphenylalanylamide were used as potential competitive inhibitors of endogenous metalloendoprotease activity. When the acrosome reaction was elicited by a potential physiological stimulus, human follicular fluid, each of the substrates (1-1.5 mM) inhibited exocytosis. Carbobenzyloxyserylleucylamide also inhibited the acrosome reaction when exocytosis was stimulated using the calcium ionophore ionomycin, but carbobenzyloxyglycylleucylamide was not inhibitory and carbobenzyloxyglycylphenylalanylamide actually enhanced exocytosis under these conditions. Experiments using the fluorescent indicator fura-2 revealed that the increase in intracellular, free calcium stimulated by follicular fluid in human spermatozoa was depressed by carbobenzyloxyglycylphenylalanylamide but not by carbobenzyloxyserylleucylamide. The peptide carbobenzyloxyglycylglycylamide, which is not a substrate for metalloendoproteases, had no effect on the acrosome reaction, whether stimulated by follicular fluid or ionomycin. While the results with carbobenzyloxyserylleucylamide suggest a possible involvement of a metalloendoprotease in the human sperm acrosome reaction, our other results demonstrate that these carbobenzyloxy peptides have complex effects on the process of exocytosis in human spermatozoa, and suggest caution in interpretation of data obtained using such peptides on intact cells.
\end{abstract}

Keywords: human; spermatozoa; acrosome reaction; metalloendoprotease substrates

\section{Introduction}

The acrosome reaction of mammalian (Yanagimachi, 1981) and invertebrate spermatozoa (Tilney, 1985 ) is a modified exocytotic event which involves fusion of the outer portion of the acrosomal membrane with the overlying plasma membrane. This fusion occurs at multiple sites resulting in fenestration of the acrosome and, ultimately, the formation of hybrid membrane vesicles which are released along with the acrosomal contents (Yanagimachi, 1981; Tilney, 1985). The acrosome reaction is most probably triggered by components of the egg investments (Monroy \& Rosati, 1983; Meizel, 1985). In mammals the acrosome reaction can only be stimulated after 'capacitation' which occurs during prolonged residence in the female reproductive tract or after incubation in certain defined media (Yanagimachi, 1981).

Recent work on model fusion systems (using erythrocytes) has suggested that proteolytic enzymes might be involved in the process of fusion (Ahkong et al., 1980; Thomas et al., 1983; Glaser \& Kosower, 1986). Indeed, studies have now demonstrated a possible role for proteases in certain physiological events involving membrane fusion. A metalloendoprotease may play a part in the fusion of developing myoblasts (Couch \& Strittmatter, 1983, 1984), in exocytosis from nerve terminals (Baxter et al., 1983), in secretion from mast cells and chromaffin cells (Mundy \& 
Strittmatter, 1985) and in the acrosome reaction of sea urchin spermatozoa (Farach et al., 1987). The majority of this work has relied upon the use of certain metalloendoprotease substrates which have been proposed to compete with the normal cellular substrate(s), thus reducing the effectiveness of the endogenous metalloendoprotease in promoting membrane fusion events (Couch \& Strittmatter, 1983; Mundy \& Strittmatter, 1985).

It has also been shown that a component of human follicular fluid, probably also present within the matrix of the cumulus oophorus at the site of fertilization, can stimulate the human sperm acrosome reaction (Suarez et al., 1986; Siiteri et al., 1988a,b). Preliminary results (Thomas et al., 1985) have demonstrated that carbobenzyloxyserylleucylamide (Cbz-Ser-Leu- $\left.\mathrm{NH}_{2}\right)$, a metalloendoprotease substrate, can inhibit the follicular fluid-stimulated acrosome reaction, a finding which further supports the proposed role for a metalloendoprotease in the process of exocytosis.

However, doubt has been cast on the specificity of these peptides by studies of their effects on adrenal chromaffin cells (Harris et al., 1986; Lelkes \& Pollard, 1987). Those results suggest that the metalloendoprotease substrates or inhibitors might exert their effects on secretion at a site distal to membrane fusion, and possibly even before generation of the second messenger (i.e. the rise in intracellular $\mathrm{Ca}^{2+}$ ). We therefore decided to investigate more fully the effect of these metalloendoprotease substrates on the human sperm acrosome reaction.

\section{Materials and Methods}

Materials. The following reagents were purchased: Cbz-Ser-Leu- $\mathrm{NH}_{2}$ from Bachem Biochemicals, Torrance, CA, USA, carbobenzyloxyglycylleucylamide (Cbz-Gly-Leu- $\mathrm{NH}_{2}$ ) and carbobenzyloxyglycylglycylamide (Cbz-Gly-Gly$\mathrm{NH}_{2}$ ) from Vega Biotechnologies, Inc., Tucson, AR, USA, and other Cbz peptides, Percoll, bovine serum albumin (BSA-Cat. No. A-7030), penicillin G (sodium salt) and streptomycin sulphate from Sigma Chemical Co., St Louis, MO, USA. Ionomycin was supplied by Calbiochem Biochemicals, La Jolla, CA, USA, and fura-2/acetoxymethyl ester (fura-2/AM) by Molecular Probes, Junction City, OR, USA.

All other chemicals were of reagent grade and were purchased from Sigma Chemical Co., Fisher Scientific Co. (Fair Lawn, NJ, USA) or Mallinckrodt, Inc. (Paris, KY, USA). USA.

Human follicular fluid was obtained from the John Muir Memorial Hospital, IVF Clinic, Walnut Creek, CA,

Preparation and incubation of cells. Human semen was obtained by masturbation from healthy donors. A population of $95 \%$ motile spermatozoa uncontaminated by seminal fluid or other cell types was obtained using a discontinuous Percoll gradient according to Suarez et al. (1986) as modified by Thomas \& Meizel (1988). The cells were washed twice (Suarez et al., 1986) and then resuspended to a concentration of $6 \times 10^{6} / \mathrm{ml}$ in an incubation medium (HSM-26B) consisting of $117.5 \mathrm{~mm}-\mathrm{NaCl}, 25 \mathrm{~mm}-\mathrm{NaHCO}_{3}, 8.6 \mathrm{~mm}-\mathrm{KCl}, 2.5 \mathrm{~mm}-\mathrm{CaCl}_{2}, 0.49 \mathrm{~mm}-\mathrm{MgCl}_{2}$, $0.3 \mathrm{~mm}-\mathrm{NaH}_{2} \mathrm{PO}_{4}, 19 \mathrm{~mm}$-sodium lactate, $2 \mathrm{~mm}$-glucose, $0.25 \mathrm{~mm}$-sodium pyruvate, $0.075 \mathrm{mg}$ penicillin $\mathrm{G} / \mathrm{ml}$, $0.05 \mathrm{mg}$ streptomycin sulphate $/ \mathrm{ml}$ and $26 \mathrm{mg} \mathrm{BSA} / \mathrm{ml}$. Samples of spermatozoa $(0.4 \mathrm{ml})$ were then capacitated at $37^{\circ} \mathrm{C}$ for $24 \mathrm{~h}$ or $40^{\circ} \mathrm{C}$ for $6 \mathrm{~h}$ in a humid atmosphere of $5 \% \mathrm{CO}_{2}-95 \%$ air ( $\mathrm{pH}$ of media $7 \cdot 4-7 \cdot 6$ ). Acrosome reactions were induced by addition of an equal volume of whole, human follicular fluid or a Sephadex G-75 fraction of follicular fluid (G-75FR) both prepared as described by Siiteri et al. (1988a) except that the follicular fluid was neither heat-treated nor buffer-exchanged before chromatography.

When acrosome reactions were induced with ionomycin, the cells were treated as described by Thomas \& Meizel (1988). Essentially, spermatozoa were capacitated for $6 \mathrm{~h}$ at $40^{\circ} \mathrm{C}$ in Medium HSM-26B, and then the BSA concentration was reduced to $3 \mathrm{mg} / \mathrm{ml}$ by washing. Ionomycin (in ethanol) was then added to a concentration of $3 \mu \mathrm{M}$ and the spermatozoa incubated for $2.5 \mathrm{~min}$. The ionophore was then quenched by addition of an equal volume of Medium HSM this time containing $50 \mathrm{mg} \mathrm{BSA} / \mathrm{ml}$ (HSM-50B) and the cells incubated for a further $17.5 \mathrm{~min}$ before fixation. Equivalent amounts of ethanol (i.e. $0.5 \%$ ) were added to the control incubations.

All the peptide substrates were dissolved in dimethylsulphoxide (DMSO) and were added to sperm suspensions $10 \mathrm{~min}$ before addition of the stimulus. Equivalent amounts of DMSO $(0.5 \%)$ were added to the control incubations.

Estimation of acrosome reactions. After addition of the various stimuli cell motility was determined, the cells were fixed (after $20 \mathrm{~min}$ ) and estimations of the acrosome reaction were obtained by indirect immunofluorescence essentially as described by Suarez et al. (1986) but with the modifications described by Thomas \& Meizel (1988). The anti-human sperm antibody used for determination of the acrosome reaction was a mouse monoclonal, HS-21, which was a generous gift from Dr Kathleen Bechtol (Genentech, South San Francisco, CA, USA).

Measurement of intracellular free $\mathrm{Ca}^{2+}$. For some experiments spermatozoa were loaded with the intracellular calcium indicator fura-2 (Grynkiewicz et al., 1985). Spermatozoa capacitated at $40^{\circ} \mathrm{C}$ for $6-5 \mathrm{~h}$ in the absence of 
glucose (Tiffert et al., 1984) were loaded essentially as described by Thomas \& Meizel (1988). After loading the cells for $30 \mathrm{~min}$ in the presence of $1 \mu \mathrm{M}$-fura-2/AM, extracellular dye was removed by centrifuging the cells through $40 \%$ Percoll. The supernatants, and as much Percoll as possible, were removed by aspiration and then the pellets taken and resuspended in $\sim 100$ volumes of Medium FM-3B $\left(125 \mathrm{~mm}-\mathrm{NaCl}, 10 \mathrm{~mm}-\mathrm{KCl}, 2.5 \mathrm{mM}-\mathrm{CaCl}_{2}, 0.5 \mathrm{mM}-\mathrm{MgCl}_{2}\right.$, $20 \mathrm{mM}$-Hepes/ $\mathrm{NaOH}$, pH 7.5 containing $20 \mathrm{M}$-sodium lactate, $2.5 \mathrm{~mm}$-sodium pyruvate and $3 \mathrm{mg} \mathrm{BSA} / \mathrm{ml})$. The cell suspension was placed in the incubator $\left(40^{\circ} \mathrm{C}\right)$ for $10 \mathrm{~min}$ before sedimenting the cells at $300 \mathrm{~g}$. The cell pellet was then resuspended to $40 \%$ of the original capacitation volume (giving a cell concentration of $\sim 10^{7} / \mathrm{ml}$ ) in Medium FM-3B.

The cells used for spectrofluorometry were kept at room temperature until needed and then $1 \mathrm{ml}$ samples were equilibrated $1040^{\circ} \mathrm{C}$ in the cuvette for $2-3 \mathrm{~min}$ before additions were made. Fluorescence was monitored using a Turner Model 430 spectrofluorometer at an excitation wavelength of $339 \mathrm{~nm}$ and an emission wavelength of $500 \mathrm{~nm}$ with an excitation slit of $15 \mathrm{~nm}$ and an emission slit of $60 \mathrm{~nm}$. Intracellular $\mathrm{Ca}^{2+}$ concentrations were estimated essentially as described by Pollock et al. (1986) using the equation:

$$
\left[\mathrm{Ca}^{2+}\right]_{\text {int }}=K_{\mathrm{d}}\left(\mathrm{F}-\mathrm{F}_{\text {min }}\right) /\left(\mathrm{F}_{\max }-\mathrm{F}\right) .
$$

$\mathrm{F}_{\max }$ was obtained by addition of $50 \mu \mathrm{M}$-digitonin and then $\mathrm{F}_{\min }$ by subsequent addition of $25 \mathrm{mM}$-EGTA (stock solution $=1 \mathrm{M}, \mathrm{pH} 8 \cdot 3)$ and sufficient $1 \mathrm{M}$-Tris to increase the $\mathrm{pH}$ above 8.3. A dissociation constant $\left(K_{\mathrm{d}}\right)$ of $224 \mathrm{nM}$ was assumed for $\mathrm{Ca}^{2+} /$ fura-2 as discussed by Grynkiewicz et al. (1985).

In these experiments $35 \mu \mathrm{l}$ ( $\sim 2 \mathrm{mg}$ protein) of the G-75FR, which had been concentrated 5-fold on an Amicon ultrafiltration unit using a filter with a 1000 molecular weight cut off, was added to $1 \mathrm{ml}$ sperm suspension in the cuvette. Appropriate corrections for dye leakage and stimulus autofluorescence were made as described previously (Thomas \& Meizel, 1988).

Electron microscopy. For transmission electron microscopy, treated human spermatozoa were washed in 20 volumes of a Hepes-buffered medium which resembled Medium HSM-26B, except that the bicarbonate was replaced with Hepes, and BSA and metabolites were omitted. The cells were sedimented at $300 \mathrm{~g}$ for $10 \mathrm{~min}$ and the pellets fixed by addition of 1.5 volumes of $3 \%$ glutaraldehyde in $5 \%$ sucrose, $0.2 \mathrm{M}$-cacodylate $\mathrm{pH} 7.4$. Fixation was carried out at room temperature for $60 \mathrm{~min}$ and then the cells were centrifuged at $9000 \mathrm{~g}$ for $1 \mathrm{~min}$. The pellet was resuspended in $5 \%$ sucrose, $0.2 \mathrm{M}$-cacodylate $\mathrm{pH} 7.4$ and recentrifuged at $9000 \mathrm{~g}$ for $1 \mathrm{~min}$. The pellet was then post-fixed according to Russell \& Burguet (1977) in an equal volume of $2 \% \mathrm{OsO}_{4}, 3 \%$ potassium ferrocyanide in Sorenson's phosphate buffer for $2 \mathrm{~h}$ and further processed as described by Dravland et al. (1984).

\section{Results}

\section{Effects of $\mathrm{Cbz}$ peptides on the acrosome reaction induced by human follicular fluid}

Human spermatozoa were stimulated to undergo the acrosome reaction by addition of human follicular fluid after capacitation for $24 \mathrm{~h}$ at $37^{\circ} \mathrm{C}$ (see Table 1). If the temperature of the incubation was raised to $40^{\circ} \mathrm{C}$ then capacitation time was significantly shortened, allowing stimulation of acrosome reactions as early as $6 \mathrm{~h}$ (see Table 2; Yudin et al., 1988). When Cbz-Ser-Leu-NH $\mathrm{NH}_{2}$ or Cbz-Gly-Leu- $\mathrm{NH}_{2}$ were added to capacitated spermatozoa $10 \mathrm{~min}$ before follicular fluid, at concentrations which inhibit fusion in other cells (Couch \& Strittmatter, 1983, 1984; Mundy \& Strittmatter, 1985), the number of acrosome reactions was dramatically reduced (Tables $1 \& 2$ ). These Cbz peptides are both considered to be substrates for certain types of neutral metalloendoproteases (Morihara, 1974). The peptide Cbz-Gly-Gly- $\mathrm{NH}_{2}$ is not thought to be a substrate for these enzymes and correspondingly had no effect on the follicular fluid-induced acrosome reaction (Table 1).

When the acrosome reaction occurs the outer acrosomal membrane fuses with the plasma membrane at several points resulting in a perforation of the two closely apposed membranes. The matrix of the vesicle is then slowly dispersed through these openings and at the same time the hybrid envelope further vesiculates and is similarly released. The monoclonal antibody (HS-21), which we use to determine acrosomal status, recognizes an acrosomal matrix antigen (Dandekar $e t$ al., 1986) and so a spermatozoon that does not stain with the antibody is scored as acrosomereacted, i.e. it has lost the acrosomal matrix. Any substance which prevents disperal of the matrix would make spermatozoa appear unreacted by indirect immunofluorescence even though membrane fusion may have occurred. Indeed, some protease inhibitors can inhibit acrosomal matrix dispersion (Green, 1978), leading to the mistaken assumption that the acrosome reaction has not taken place. Therefore it is necessary to check the morphology of the acrosome reaction at the electron microscope level to be certain that the peptides inhibit the fusion event, not merely 
Table 1. The effects of Cbz-Ser-Leu-NH $\mathrm{N}_{2}$ and Cbz-GlyGly- $\mathrm{NH}_{2}$ on the human sperm acrosome reaction induced by human follicular fluid (hff)

\begin{tabular}{|c|c|c|}
\hline Treatment & $\begin{array}{c}\text { Motility } \\
(\%)\end{array}$ & $\begin{array}{c}\text { Acrosome } \\
\text { reactions } \\
(\%)\end{array}$ \\
\hline $\begin{array}{l}\text { Control (Medium HSM-26B) } \\
\text { hff } \\
\text { hff }+ \text { Cbz-Ser-Leu-NH } \mathrm{NH}_{2}(1 \mathrm{mM}) \\
\mathrm{hff}+\text { Cbz-Gly-Gly-NH } \mathrm{NH}_{2}(1 \mathrm{mM})\end{array}$ & $\begin{array}{l}86 \pm 3 \\
86 \pm 4 \\
86 \pm 1 \\
85 \pm 3\end{array}$ & $\begin{array}{r}8 \pm 3^{a} \\
28 \pm 9^{b} \\
13 \pm 4^{a} \\
24 \pm 6^{b}\end{array}$ \\
\hline
\end{tabular}

Spermatozoa were capacitated for $24 \mathrm{~h}$ at $37^{\circ} \mathrm{C}$ and then treated with hff for $20 \mathrm{~min}$ in the presence or absence of the $\mathrm{Cbz}$ peptides $(10 \mathrm{~min}$ preincubation). Values are mean \pm s.d. for 6 observations.

${ }^{a, b}$ Values with different superscripts are significantly different $(P<0.01)$ using the Dunnett $t$ test for multiple comparisons.

Table 2. The effects of Cbz-Ser-Leu-NH $\mathrm{N}_{2}$ and Cbz-GlyLeu- $\mathrm{NH}_{2}$ on the human sperm acrosome reaction induced by human follicular fluid (hff)

\begin{tabular}{lcc}
\hline \multicolumn{1}{c}{ Treatment } & $\begin{array}{c}\text { Motility } \\
(\%)\end{array}$ & $\begin{array}{c}\text { Acrosome } \\
\text { reactions } \\
(\%)\end{array}$ \\
\hline Control (Medium HSM-26B) & $89 \pm 5$ & $5 \pm 3$ \\
hff & $89 \pm 5$ & $31 \pm 14^{\mathrm{a}}$ \\
hff + Cbz-Ser-Leu-NH $(1 \mathrm{mM})$ & $89 \pm 8$ & $14 \pm 6^{\mathrm{b}}$ \\
hff + Cbz-Gly-Leu-NH $\mathrm{NH}_{2}(1 \mathrm{mM})$ & $90 \pm 5$ & $20 \pm 11^{\mathrm{b}}$ \\
hff + Cbz-Gly-Leu-NH $2(1 \cdot 5 \mathrm{mM})$ & $90 \pm 5$ & $16 \pm 9^{\mathrm{b}}$ \\
\hline
\end{tabular}

Spermatozoa were capacitated for $6 \mathrm{~h}$ at $40^{\circ} \mathrm{C}$ and then treated with hff for $20 \mathrm{~min}$ in the presence or absence of the $\mathrm{Cbz}$ peptides $(10 \mathrm{~min}$ preincubation). Values are mean $\pm \mathrm{s}$.d. for 6 observations.

${ }^{\mathrm{a}, \mathrm{b}}$ Values with different superscripts were significantly different $(P<0.01)$ using the Dunnett $t$ test for multiple comparisons.

All samples treated with hff were significantly different from the control $(P<0 \cdot 05)$.

dispersion of the matrix. Figure 1 shows representative spermatozoa from an incubation in which spermatozoa were treated with follicular fluid in the presence of Cbz-Ser-Leu-NH $\mathrm{N}_{2}$. In this and a further experiment the average number of acrosome reactions in spermatozoa treated with follicular fluid alone was $40 \%$ as determined by immunofluorescence and $41 \%$ as determined by electron microscopy. In the presence of $\mathrm{Cbz}-\mathrm{Ser}-\mathrm{Leu}-\mathrm{NH}_{2}$, acrosome reactions were reduced to $19 \%$ as judged by both immunofluorescence and electron microscopy. In all experiments, when viewed by electron microscopy the spermatozoa treated with $\mathrm{Cbz}$ peptides looked normal both with respect to overall structure and, more specifically, to the morphology of the acrosome reaction (cf. Fig. 1 to Suarez et al. 1986).

Another peptide containing hydrophobic residues, carbobenzyloxyleucyltyrosylamide (CbzLeu-Tyr- $\mathrm{NH}_{2}$ ), was also tested for its effects on the acrosome reaction. This peptide is a substrate for metalloendoproteases which recognize a hydrophobic amino acid in the $\mathrm{P}_{1}$ subsite (Morihara, 1974). It must be deduced from the sequences of the peptides which inhibit cellular fusion events 

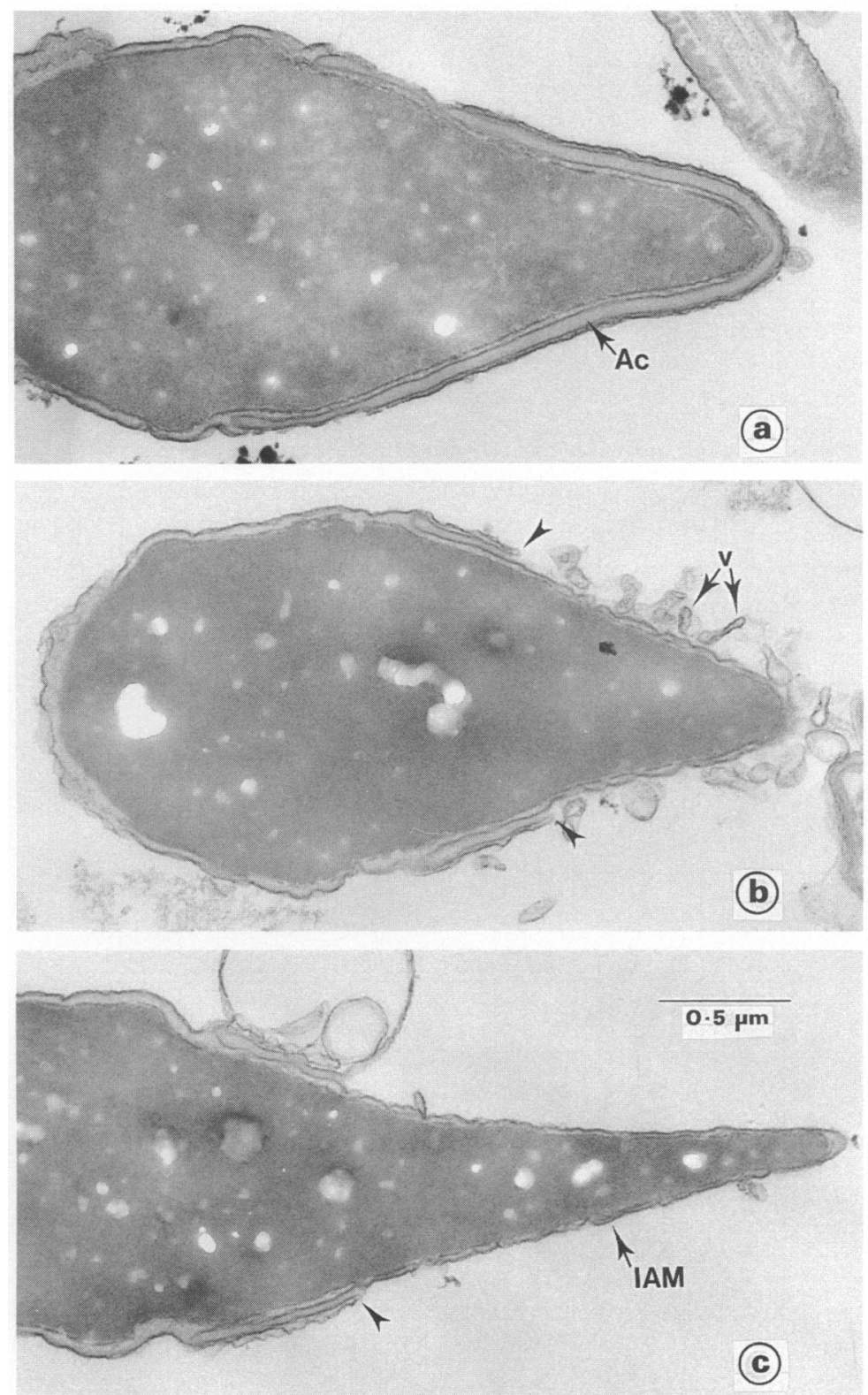

Fig. 1. Transmission electron microscopy of human spermatozoa capacitated at $37^{\circ} \mathrm{C}$ for $24 \mathrm{~h}$ and then treated with human follicular fluid for $20 \mathrm{~min}$ in the presence of $1 \mathrm{~mm}$-Cbz-Ser-Leu$\mathrm{NH}_{2}$ (10 min preincubation). (a) Acrosome intact spermatozoa; (b and c) acrosome-reacted spermatozoa. $\mathrm{Ac}=$ Acrosome $\mathrm{v}=$ Hybrid vesicles formed by the fusion of the outer acrosomal membrane with the plasma membrane. IAM = inner acrosomal membrane. Arrow heads denote point of fusion between the plasma membrane and the remaining outer acrosomal membrane (indicative of a physiological acrosome reaction). 
(Couch \& Strittmatter, 1983, 1984; Mundy \& Strittmatter, 1985) that the metalloendoprotease involved in membrane fusion would act on substrates with hydrophobic amino acids in the $\mathbf{P}_{\mathbf{1}}{ }^{\prime}$ subsite. Therefore Cbz-Leu-Tyr- $\mathrm{NH}_{2}$ would not be expected to inhibit the acrosome reaction. However, this peptide proved to be a potent inhibitor of the follicular fluid-stimulated acrosome reaction at a concentration of $1 \mathrm{~mm}$ (control $=10 \pm 3 \%$; follicular fluid $=36 \pm 10 \%$; follicular fluid + Cbz-Leu-Tyr- $\mathrm{NH}_{2}=13 \pm 5 \%$; \% acrosome reactions \pm s.d., $n=6$ ).

When human follicular fluid was fractionated using a Sephadex G-75 column, a fraction with an apparent molecular weight of 50000 (G-75FR) was found to contain acrosome reactionstimulating activity (Suarez et al., 1986; Siiteri et al., 1988a). The acrosome reaction induced by this fraction in spermatozoa capacitated for $24 \mathrm{~h}$ at $37^{\circ} \mathrm{C}$ was also inhibited by Cbz-Ser-Leu- $\mathrm{NH}_{2}$ (control $=17 \pm 4 \% ;$ G-75FR $=40 \pm 17 \%$; G-75FR +1 mM-Cbz-Ser-Leu-NH ${ }_{2}=21 \pm 4 \% ; \%$ acrosome reactions \pm s.d., $n=3$ ).

\section{Effects of $\mathrm{Cbz}$ peptides on the ionomycin-induced acrosome reaction}

Treatment of spermatozoa with divalent cation ionophores generally leads to a dramatic loss of motility (Reed \& Lardy, 1972). However, this deleterious effect on motility can be avoided if the cells are only briefly exposed to the ionophore (Thomas \& Meizel, 1988). In these experiments capacitated spermatozoa were treated with ionomycin $(3 \mu \mathrm{M})$ for only $2.5 \mathrm{~min}$, before the ionophore was quenched with excess BSA. Such brief exposure to the ionophore is sufficient to induce acrosome reactions without adversely affecting cell motility (see Table 3 ; and Thomas $\&$ Meizel, 1988).

Table 3. The effects of $\mathrm{Cbz}$ peptides on the ionomycin-induced human sperm acrosome reaction

\begin{tabular}{|c|c|c|}
\hline Treatment & $\begin{array}{c}\text { Motility } \\
(\%)\end{array}$ & $\begin{array}{c}\text { Acrosome } \\
\text { reactions } \\
(\%)\end{array}$ \\
\hline Control $(0.5 \%$ EtOH $)$ & $91 \pm 2$ & $7 \pm 2$ \\
\hline Ionomycin $(3 \mu \mathrm{M})$ & $90 \pm 3$ & $34 \pm 7^{a}$ \\
\hline Ionomycin + Cbz-Ser-Leu-NH ${ }_{2}(1 \mathrm{~mm})$ & $89 \pm 2$ & $23 \pm 11^{\mathrm{b}}$ \\
\hline Ionomycin + Cbz-Gly-Leu-NH ${ }_{2}(1 \mathrm{mM})$ & $89 \pm 1$ & $35 \pm 8^{a}$ \\
\hline Ionomycin + Cbz-Gly-Phe-NH ${ }_{2}(1 \mathrm{mM})$ & $87 \pm 2$ & $47 \pm 10^{\mathrm{c}}$ \\
\hline Ionomycin + Cbz-Gly-Gly-NH $(1 \mathrm{mM})$ & $89 \pm 2$ & $34 \pm 11^{2}$ \\
\hline
\end{tabular}

Spermatozoa were capacitated for $6 \mathrm{~h}$ at $40^{\circ} \mathrm{C}$ and then treated with $3 \mu \mathrm{M}$-ionomycin in the presence or absence of the $\mathrm{Cbz}$ peptides $(10 \mathrm{~min}$ preincubation). Values are mean \pm s.d. for 5 observations.

a,b.c Values with different superscripts were significantly different $(P<0.05)$ using the Dunnett $t$ test for multiple comparisons.

All samples treated with ionomycin were significantly different from the control $(P<0.05)$.

Three potential metalloendoprotease substrates (all Cbz peptides) were tested for their effects on ionomycin-induced acrosome reactions (Table 3). Each peptide had a different effect on the number of spermatozoa undergoing the acrosome reaction. Cbz-Ser-Leu- $\mathrm{NH}_{2}$ showed a small, but significant, inhibition of ionomycin-stimulated acrosome reactions, whereas Cbz-Gly-Leu- $\mathrm{NH}_{2}$ had no effect. In contrast, another metalloendoprotease substrate (Morihara, 1974) carbobenzyloxyglycylphenylalanylamide (Cbz-Gly-Phe- $\mathrm{NH}_{2}$ ) had a slight stimulatory effect on the acrosome reaction induced by ionomycin. As was seen with follicular fluid-induced acrosome reactions, the peptide Cbz-Gly-Gly- $\mathrm{NH}_{2}$, which is not a metalloendoprotease substrate, had no significant effect on acrosome reactions induced by ionomycin. 


\section{Effects of $\mathrm{Cbz}$ peptides on the increase in $\left[\mathrm{Ca}^{2+}\right]_{\text {int }}$ induced by $\mathrm{G}-75 F R$}

When spermatozoa, capacitated at $40^{\circ} \mathrm{C}$ for $6.5 \mathrm{~h}$, were treated with $\mathrm{G} \cdot 75 \mathrm{FR}$ a large, transient increase in intracellular, free $\mathrm{Ca}^{2+}$ was detected using the fluorescent indicator fura-2 (Fig. 2a). It can be seen from Fig. 2(b) that the rise in intracellular, free $\mathrm{Ca}^{2+}$ was significantly lower in the presence of Cbz-Gly-Phe- $\mathrm{NH}_{2}$ than with G-75FR alone, whilst Cbz-Ser-Leu- $\mathrm{NH}_{2}$ showed no significant effect (Fig. 2c). Similarly, in two experiments (results not shown) the peptide Cbz-GlyGly- $\mathrm{NH}_{2}$, which is not a metalloendoprotease substrate, had no significant effect. Motility was assessed after completion of each experiment and was always $85-90 \%$. None of the peptides used was autofluorescent, nor did they have any effect on the fluorescence of fura- 2 free in solution (unpublished observations). Occasionally a small, transient increase in fluorescence of fura-2-loaded spermatozoa was seen soon after addition of $\mathrm{Cbz}-\mathrm{Ser}-\mathrm{Leu}-\mathrm{NH}_{2}$. This observation is similar to that seen by Lelkes \& Pollard (1987) using Cbz-Gly-Leu-NH ${ }_{2}$, but this direct effect of Cbz-Ser-Leu- $\mathrm{NH}_{2}$ on the fluorescence of fura-2-loaded spermatozoa was not consistently reproducible.

(a)

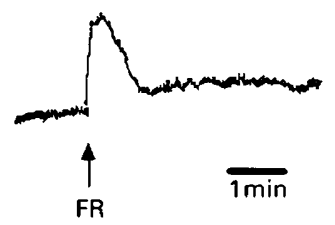

(b)

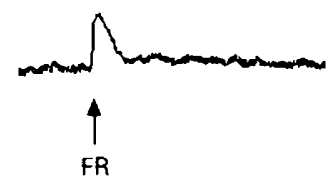

(c)

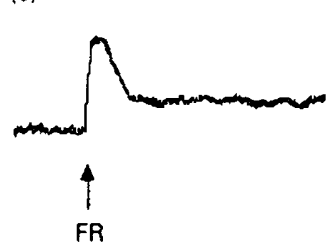

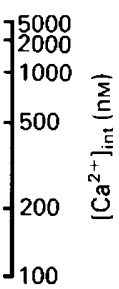

Fig. 2. The effect of $\mathrm{Cbz}$ peptides on the rise in human sperm $\left[\mathrm{Ca}^{2+}\right]_{\text {int }}$ induced by G-75FR (FR). Spermatozoa were loaded with fura- 2 after capacitation for $6.5 \mathrm{~h}$ at $40^{\circ} \mathrm{C}$. The cells were then treated with concentrated G-75FR in the presence or absence of $\mathrm{Cbz}$ peptides $(10 \mathrm{~min}$ preincubation). This was one of three similar experiments. (a) Spermatozoa + G-75FR. (b) Spermatozoa + 1 mm-Cbz-Gly-Phe- $\mathrm{NH}_{2}+\mathrm{G}-75 \mathrm{FR}$. (c) Spermatozoa $+1 \mathrm{~mm}$-Cbz-Ser-Leu$\mathrm{NH}_{2}+\mathrm{G}-75 \mathrm{FR}$.

\section{Discussion}

The results of our experiments present a complex picture of the effect of metalloendoprotease substrates on exocytosis in human spermatozoa. All three metalloendoprotease substrates studied, Cbz-Ser-Leu- $\mathrm{NH}_{2}$, Cbz-Gly-Leu- $\mathrm{NH}_{2}$ and Cbz-Gly-Phe- $\mathrm{NH}_{2}$ (results not shown) blocked the acrosome reaction initiated by the potential physiological stimulus (either follicular fluid or G-75FR) under a variety of conditions. However, each peptide had a different effect on ionomycininduced acrosome reactions. These variable effects are difficult to reconcile with the hypothesis that each of these peptides acts solely on a metalloendoprotease which is involved in the process of acrosomal vesicle/plasma membrane fusion.

Other workers have previously cast doubt on the proposed role of a metalloendoprotease in the membrane fusion step of agonist-stimulated secretion (Harris et al., 1986; Lelkes \& Pollard, 1987). Harris et al. (1986) and Lelkes \& Pollard (1987), using adrenal chromaffin cells, demonstrated that metalloendoprotease substrates could block the rise in intracellular $\mathrm{Ca}^{2+}$ stimulated by the agonist nicotine. Our experiments likewise show a dramatic reduction in the $\mathrm{Ca}^{2+}$ transient stimulated by G-75FR in the presence of Cbz-Gly-Phe- $\mathrm{NH}_{2}$, which further suggests that metalloendoproteases might play a role in secretion at a step involved in $\mathrm{Ca}^{2+}$ mobilization (Lelkes \& Pollard, 1987). However, our results using Cbz-Ser-Leu- $\mathrm{NH}_{2}$ do not support this hypothesis. Very little, if any, effect of this peptide on $\mathrm{Ca}^{2+}$ mobilization was observed in spermatozoa, and yet this metalloendoprotease substrate is a potent inhibitor of the acrosome reaction. 
Our results on ionomycin-stimulated exocytosis also cast doubt on the specificity of these peptides. If a metalloendoprotease were involved in the membrane fusion step of secretion then the peptides would be expected to be equally potent inhibitors of ionophore-induced secretion as they are of agonist-induced secretion. However, of the three substrates tested, only Cbz-Ser-Leu- $\mathrm{NH}_{2}$ showed any inhibition of the ionophore-stimulated acrosome reaction. In contrast Cbz-Gly-Phe$\mathrm{NH}_{2}$, which was shown to augment ionomycin-stimulated secretion in adrenal chromaffin cells (Harris et al., 1986), actually enhanced ionophore-stimulated exocytosis in human spermatozoa.

Aiello et al. (1986) have suggested that the substrate Cbz-Gly-Phe- $\mathrm{NH}_{2}$ might have membrane perturbant effects. This proposal is based on the ability of this peptide both to inhibit insulinactivated glucose transport (in adipocytes) and, more pertinently, to induce shape changes in erythrocytes. Similarly, Epand et al. (1987), from differential scanning calorimetry studies, have suggested that $\mathrm{Cbz}-\mathrm{Ser}-\mathrm{Leu}-\mathrm{NH}_{2}$ might stabilize phospholipid bilayers and prevent phospholipids from forming non-bilayer configurations. It therefore seems that these peptides may have complex effects on membrane structure and function. The inhibition of the G-75FR-induced $\mathrm{Ca}^{2+}$ transient and the enhancement of the ionomycin-induced acrosome reactions by Cbz-Gly-Phe$\mathrm{NH}_{2}$ could both be explained by such membrane perturbant properties. Disruption of the normal membrane microenvironment could affect receptor function, and thus decrease the $\mathrm{Ca}^{2+}$ transient, either by reducing agonist/receptor binding or by interfering with the coupling of the 'activated' receptor to $\mathrm{Ca}^{2+}$ mobilization. In contrast, if both agonist/receptor binding and receptor $/ \mathrm{Ca}^{2+}$ mobilization coupling are bypassed by use of a $\mathrm{Ca}^{2+}$ ionophore, it is possible that the same membrane disturbance might physically facilitate the fusion process and therefore enhance the ionomycin-induced acrosome reaction. Similarly, the inhibition of the follicular fluidstimulated acrosome reaction by Cbz-Leu-Tyr- $\mathrm{NH}_{2}$ (which would not be expected to have the same active site specificity as the other peptides) may be explained by such membrane perturbant properties.

The results obtained with Cbz-Ser-Leu- $\mathrm{NH}_{2}$ are more consistent with the hypothesis that these peptides act on a metalloendoprotease which is involved in membrane fusion phenomena. However, Cbz-L-phenylalanine, a competitive inhibitor of metalloendoproteases (Burstein et al., 1974), did not inhibit the human sperm acrosome reaction stimulated by human follicular fluid (Diaz-Perez et al., 1988).

In experiments on the sea urchin sperm acrosome reaction, using other metalloendoprotease substrates and inhibitors (Farach et al., 1987), the substrates used did not affect $\mathrm{Ca}^{2+}$ uptake (as measured using ${ }^{45} \mathrm{Ca}$ ). Taken together with the data obtained with crude metalloendoprotease preparations and from localization studies in various tissues (Couch \& Strittmatter, 1984; Mundy \& Strittmatter, 1985), this may reflect a true involvement of metalloendoprotease activity in the process of membrane fusion. However, our results on human spermatozoa, along with other studies using Cbz peptides (Harris et al., 1986; Lelkes \& Pollard, 1987; Aiello et al., 1986; Epand et al., 1987), suggest that extreme caution should be exercised when interpreting data obtained using such peptides on intact cells.

We thank Dr Kathleen Bechtol (Genentech, South San Francisco, CA, USA) for providing the mouse anti-human sperm mAB, HS-21; Mr Robert Munn for preparing the electron micrographs; and Ms Diane Cranz and Mr Richard Osman for critical reading of the manuscript. This work was supported by NIH grant HD06698 to S.M.

\section{References}

Ahkong, Q.F., Botham, G.M., Woodward, A.W. \& Lucy, J.A. (1980) $\mathrm{Ca}^{2+}$-activated thiol protease activity in the fusion of rat erythrocytes induced by benzyl alcohol. Biochem. J. 192, 829-836.

Aiello, L.P., Wessling-Resnick, M. \& Pilch, P.F. (1986) Dipeptide metalloendoprotease substrates are glucose transport inhibitors and membrane structure perturbants. Biochemistry, N.Y. 25, 3944-3950.

Baxter, D.A., Johnston, D. \& Strittmatter, W.J. (1983) Protease inhibitors implicate metalloendoprotease in synaptic transmission at the neuromuscular junction. Proc. natn. Acad. Sci. U.S.A. 80, 41744178. 
Burstein, Y., Walsh, K.A. \& Neurath, H. (1974) Evidence of an essential histidine residue in thermolysin. Biochemistry, N.Y. 13, 205-210.

Couch, C.B. \& Strittmatter, W.J. (1983) Rat myoblast fusion requires metalloendoprotease activity. Cell 32, 257-265.

Couch, C.B. \& Strittmatter, W.J. (1984) Specific blockers of myoblast fusion inhibit a soluble and not the membrane-associated metalloendoprotease in myoblasts. J. biol. Chem. 259, 5396-5399.

Dandekar, P., Talbot, P. \& Bechtol, K. (1986) Localization of monoclonal antibody binding sites in human sperm using immunoelectron microscopy. J. Cell Biol. 103, 240a, Abstr.

Diaz-Perez, E., Thomas, P. \& Meizel, S. (1988) Evidence suggesting a role for sperm metalloendoprotease activity in the penetration of zona-free hamster eggs by human sperm. J. exp. Zool. (in press).

Dravland, J.E., Llanos, M.N., Munn, R.J. \& Meizel, S. (1984) Evidence for the involvement of a sperm trypsin-like enzyme in the membrane events of the hamster sperm acrosome reaction. J. exp. Zool. 232, $117-128$

Epand, R.M., Lobl, T.J. \& Renis, H.E. (1987) Bilayer stabilizing peptides and the inhibition of viral infection: antimeasles activity of carbobenzoxy-Ser-Leuamide. Biosci. Reports 7, 745-749.

Farach, H.A., Jr, Mundy, D.I., Strittmatter, W.J. \& Lennarz, W.J. (1987) Evidence for the involvement of metalloendoproteases in the acrosome reaction in sea urchin sperm. J. biol. Chem. 262, 5483-5487.

Glaser, T. \& Kosower, N.S. (1986) Fusion of rat erythrocytes by membrane-mobility agent $\mathrm{A}_{2} \mathrm{C}$ depends on membrane proteolysis by a cytoplasmic calpain. Eur. J. Biochem. 159, 387-392.

Green, D.P.L. (1978) The activation of proteolysis in the acrosome reaction of guinea pig sperm. J. Cell Sci. 32, $153-164$.

Grynkiewicz, G., Poenie, M. \& Tsien, R.Y. (1985) A new generation of $\mathrm{Ca}^{2+}$ indicators with greatly improved fluorescent properties. J. biol. Chem. 260, 3440-3450.

Harris, B., Cheek, T.R. \& Burgoyne, R.D. (1986) Effects of metalloendoproteinase inhibitors on secretion and intracellular free calcium in bovine adrenal chromaffin cells. Biochim. Biophys. Acta 889, 1-5.

Lelkes, P.I. \& Pollard, H.B. (1987) Oligopeptide inhibitors of metalloendoprotease activity inhibit catecholamine secretion from bovine adrenal chromaffin cells by modulating intracellular calcium homeostasis. $J$. biol. Chem. 262, 15496-15505.

Meizel, S. (1985) Molecules that initiate or help stimulate the acrosome reaction by their interaction with the sperm surface. Am. J. Anat. 174, 285-302.

Monroy, A. \& Rosati, F. (1983) A comparative analysis of sperm-egg interaction. Gamete Res. 7, 85-102.

Morihara, K. (1974) Comparative specificity of microbial proteinases. Adv. Enzymol. 41, 179-243.

Mundy, D.I. \& Strittmatter, W.J. (1985) Requirement for metalloendoprotease in exocytosis: evidence in mast cells and adrenal chromaffin cells. Cell $\mathbf{4 0}$, 645-656.

Pollock, W.K., Rink, T.J. \& Irvine, R.F. (1986) Liberation of $\left[{ }^{3} \mathrm{H}\right]$ arachidonic acid and changes in cytosolic free calcium in fura-2-loaded human platelets stimulated by ionomycin and collagen. Biochem. J. 235, 869-877.

Reed, P.W. \& Lardy, H.A. (1972) Antibiotic A23187 as a probe for the study of calcium and magnesium function in biological systems. In The Role of Membranes in Metabolic Regulation, pp. 111-131. Eds M. A. Mehlman \& R. W. Hanson. Academic Press, New York.

Russell, L. \& Burguet, S. (1977) Ultrastructure of Leydig cells as revealed by secondary tissue treatment with a ferrocyanide-osmium mixture. Tissue and Cell 9, $751-766$.

Siiteri, J.E., Gottlieb, W. \& Meizel, S. (1988a) Partial characterization of a fraction from human follicular fluid which initiates the human sperm acrosome reaction in vitro. Gamete Res. 20, 25-42.

Siiteri, J.E., Dandekar, P. \& Meizel, S. (1988b) Human sperm acrosome reaction-initiating activity associated with the human cumulus oophorus and mural granulosa cells. J. exp. Zool. 246, 71-80.

Suarez, S.S., Wolf, D.P. \& Meizel, S. (1986) Induction of the acrosome reaction in human spermatozoa by a fraction of human follicular fluid. Gamete Res. 14, $107-121$.

Thomas, P. \& Meizel, S. (1988) An influx of extracellular calcium is required for initiation of the human sperm acrosome reaction induced by human follicular fluid. Gamete Res. 20, 397-411.

Thomas, P., Limbrick, A.R. \& Allan, D. (1983) Limited breakdown of cytoskeletal proteins by an endogenous protease controls $\mathrm{Ca}^{2+}$-induced membrane fusion events in chicken erythrocytes. Biochim. Biophys. Acta 730, 351-358.

Thomas, P., Gottlieb, W. \& Meizel, S. (1985) Is there a role for sperm metalloendoprotease activity in the human sperm acrosome reaction? J. Cell Biol. 101, 227a, Abstr.

Tiffert, T., Garcia-Sancho, J. \& Lew, V.L. (1984) Irreversible ATP depletion caused by low concentrations of formaldehyde and of calcium-chelator esters in intact human red cells. Biochim. Biophys. Acta 773, 143156.

Tilney, L.G. (1985) The acrosomal reaction. In The Biology of Fertilization, vol. 2, pp. 157-213. Eds C. B. Metz \& A. Monroy. Academic Press, New York.

Yanagimachi, R. (1981) Mechanisms of fertilization in mammals. In Fertilization and Embryonic Development, pp. 81-182. Eds L. Mastroianni Jr \& J. D. Biggers. Plenum Press, New York.

Yudin, A.I., Gottlieb, W.I. \& Meizel, S. (1988) Ultrastructural studies of the early events of the human sperm acrosome reaction as initiated by human follicular fluid. Gamete Res. 20, 14-22.

Received 8 June 1988 